\title{
Pengaruh Pembelajaran Melalui Program TVRI Terhadap Aspek Psikomotorik Siswa SD di Masa Pandemi Covid-19
}

\author{
Eva Luthfi Fakhru Ahsani ${ }^{1}$, Ayuningsih ${ }^{2}$ \\ Institut Agama Islam Negeri Kudus, Indonesia \\ evaluthfi@iainkudus.ac.id \\ ayu62134@gmail.com
}

\begin{abstract}
The learning program through the TVRI program can make it easier for students who have obstacles to access the internet, due to economic reasons and geographic location. This study aims to examine the effect of learning from home through TVRI on the psychomotor aspects of elementary school students during the spread of Covid-19. There are 3 levels studied, namely readiness, guidance, and basic skills. The method used in this research is descriptive qualitative. The research subjects included students in grades III, IV, and V SDN Jambean 02. The data filling technique was an instrument in the form of observation and structured interviews. Learning from home through the TVRI learning program guided by parents or adults, affects the psychomotor aspects of students at the readiness and guidance stages, but at the basic skilled stage it has not been successful. This shows the role of teachers in schools cannot be saved by technology, even when students study at home accompanied by parents. With the learning from home through the TVRI program, it is hoped that parents can read students when studying, with the aim of developing students' psychomotor aspects optimally.
\end{abstract}

Keywords: TVRI Program Learning, Psychomotor Aspects, Covid-19 Pandemic

\begin{abstract}
Abstrak: Program pembelajaran melalui program TVRI dapat memudahkan siswa yang mempunyai hambatan dalam mengakses internet, karena alasan ekonomi maupun letak geografis. Penelitian ini bertujuan untuk meneliti adanya pengaruh pembelajaran dari rumah melalui TVRI terhadap aspek psikomotorik siswa SD selama penyebaran covid-19, ada 3 tingkat yang diteliti yaitu kesiapan, pembimbingan, dan terampil dasar. Metode yang digunakan dalam penelitian ini adalah deskriptif kualitatif. Subyek penelitian meliputi siswa kelas III, IV, dan V SDN Jambean 02. Teknik pengumpulan data yaitu instrumen berupa observasi dan wawancara terstruktur. Belajar dari rumah lewat program belajar
\end{abstract}

AR-RIAYAH : Jurnal Pendidikan Dasar vol. 4, no. 2, 2020

IAIN Curup - Bengkulu l p ISSN 2580-362X; e ISSN 2580-3611

http://journal.iaincurup.ac.id/index.php/JPD

DOI: $10.29240 /$ jpd.v4i2.1594 | p. $145-154$ 
TVRI dengan bimbingan orang tua atau orang dewasa, berpengaruh terhadap aspek psikomotorik siswa pada tahap kesiapan dan pembimbingan, namun pada tahap terampil dasar belum berhasil. Hal ini menunjukkan peran guru di sekolah tidak bisa digantikan oleh teknonogi, meskipun ketika siswa belajar di rumah didampingi oleh orang tua. Dengan adanya pembelajaran dari rumah melalui program TVRI, diharapkan orang tua dapat membimbing siswa ketika belajar, dengan tujuan supaya aspek psikomotorik siswa berkembang secara optimal.

Kata kunci: Pembelajaran Program TVRI, Aspek Psikomotorik, Pandemi Covid-19

\section{PENDAHULUAN}

Mendikbud bekerjasama dengan TVRI sejak senin 13 April 2020 dengan meluncurkan sejumlah program pembelajaran muliai dari tingkat PAUD, SD, SMP, sampai tingkatan SMA. Program pembelajaran melalui TVRI bertujuan untuk memudahkan siswa yang memiliki hambatan dalam mengakses internet disebabkan oleh faktor ekonomi maupun letak geografis. Mendikbud Nadiem Makarim menjelaskan fokus pembelajaran melalui TVRI meliputi pengembangan literasi, numerasi, dan karakter siswa. Dalam program tersebut, siswa dapat mengikuti tayangan pembelajaran yang diberikan sesuai dengan tingkatan yang telah ditentukan dan kemudian mencatat soal yang telah diberikan. ${ }^{1}$ Program pembelajaran ini dilakukan sebagai upaya untuk mengurangi penularan covid-19.

Dengan adanya program TVRI sebagai alternatif pembelajaran yang dilaksanakan dari rumah, dalam pelaksanaannya berkaitan dengan aspek psikomotorik siswa. Aspek psikomotorik adalah pengetahuan siswa berdasarkan perkembangan proses mental melalui pergerakan otot, dalam perkembangannya aspek psikomotorik selain menggerakkan otot, mempengaruhi perkembangan pengetahuan berkaitan dengan kecakapan hidup. ${ }^{2}$ Aspek psikomotorik sebagai hasil belajar siswa berhubungan dengan keterampilan fisik untuk melakukan pekerjaan atau tugas. Melalui belajar akan melatih siswa terampil untuk melalukan aktivitas yang lebih baik dari sebelumnya.

\section{Program Belajar di Masa Covid-19}

Kegiatan pembelajaran di rumah adalah kebijakan Mendikbud untuk membantu terselenggaranya pendidikan di kalangan masyarakat pada masa darurat pandemi covid-19. Program TVRI merupakan saluran gratis yang bisa

1 Indira Rezkisari, Belajar Lewat TVRI tak. Bisa Gantikan Program Buatan Sekolah, Selasa 14 April 2020,

2 Sukardi, Evaluasi Pendidikan: Prinsip dan Operasionalnya, (Jakarta: Bumi Aksara, 2009), hal. 76 
diakses oleh masyarakat dari berbagai daerah dan dapat dimanfaatkan oleh siswa, guru, dan orang tua ketika melaksanakan pembelajaran di rumah selama pandemi covid-19. ${ }^{3}$ Belajar melalui program TVRI akan dimulai pada 13 April 2020. Pada hari senin sampai jum'at, akan disiarkan acara yang berkaitan dengan materi pebelajaran dengan alokasi waktu tiga jam sehari mulai dari jenjang PAUD, SD, SMP, sampai SMA, namun di akhir pekan berisi tentang berbagai konten kebudayaan.

\section{Permasalahan Belajar Melalui Program TVRI}

Berdasarkan hasil penelitian yang peneliti lakukan terhadap siswa SDN Jambean 02 Pati mengenai pembelajaran dari rumah selama penyebaran covid-19, melalui program TVRI. Peneliti menemukan permasalahan yaitu adanya siswa yang belum memahami materi yang disampaikan, yang disebabkan beberapa faktor diantaranya, penyampaian materi terlalu cepat atau singkat sehingga ada siswa yang belum bisa memahami, siswa kurang konsentrasi ketika menyimak materi yang disampaikan, kurangnya minat siswa untuk belajar, dan adanya siswa yang masih bingung terkait tugas atau soal yang diberikan setelah materi selesai disampaikan.

\section{Cara Mengatasi Permasalahan yang ada}

Berdasarkan permasalahan yang peneliti temukan, bisa diatasi dengan adanya ulasan atau penguatan materi dari guru kelas setelah materi program TVRI selesai disampaikan. Adanya dukungan dari orang tua atau orang dewasa sangat diperlukan supaya siswa lebih semangat ketika belajar, dan jika memungkinkan orang tua atau orang dewasa bisa membantu dan membimbing ketika siswa memahami materi ataupun mengerjakan tugas yang diberikan.

\section{Pengaruh Program TVRI Terhadap Psikomotorik Siswa}

Penelitian ini bertujuan untuk meneliti adanya pengaruh pembelajaran dari rumah melalui program TVRI terhadap aspek psikomotorik siswa SD selama penyebaran covid-19, ada 3 tingkat yang diteliti yaitu kesiapan (set), pembimbingan (guided response), terampil dasar (mechanism). Pada tahapan kesiapan (set) menunjukkan kesiapan siswa untuk melakukan tugas yang diberikan dan mengetahui langkah-langkah untuk melakukan tugas tersebut. Dilanjut dengan tahap pembimbingan (guided response), pada tahap ini siswa meniru atau mencoba atas apa yang telah dicontohkan dan adakalanya siswa gagal, dengan kata lain kemampuan dapat dicapai dengan berlatih. Pada tahap terampil dasar (mechanism), siswa dapat melakukan kebiasaan dan gerakan dengan percaya diri. ${ }^{4}$ Pencapaian aspek psikomotorik siswa dipengaruhi oleh adanya persepsi dan kesiapan, selain

3 Yohanes Enggar Harususilo, Belajar dari Rumab Lewat TVRI, Berikut Tayangan yang Akan Diberikan, Jum'at 10 April 2020.

hal. 46

4 Didi Nur Jamaluddin, Pengembangan Evaluasi Pembelajaran (Kudus: IAIN Kudus, 2018), 
itu adanya bimbingan dari guru maupun orang tua dapat mendukung siswa untuk mencapai beberapa tahapan aspek psikomotorik.

Pembelajaran ditengah pandemi covid-19 yang dilaksanakan dari rumah melalui program TVRI diharapkan dapat berpengaruh terhadap aspek psikomotorik siswa, karena belajar dari rumah memungkinkan siswa memperoleh bimbingan dari orang tua atau orang dewasa yang akan membantu mengembangkan aspek psikomotorik, disamping bimbingan dari guru kelas.

\section{Belajar di Kelas}

Berbeda dengan pembelajaran yang dilaksanakan di dalam kelas, terjadi interaksi langsung antara guru dan siswa, seperti penelitian yang dilakukan oleh Ramdhan Witarsa dkk, pada tahun 2017 yang berjudul "Meningkatkan Kemampuan Aspek Psikomotorik Siswa Sekolah Dasar Melalui Hands On Activity di Kota Cimahi" pada penelitian tersebut, menunjukkan adanya peningkatan kemampuan aspek psikomotorik siswa SD melalui HOA dengan memberikan berbagai macam cara belajar yang menggerakkan dan menggunakan tangan sebesar $23 \% .^{5}$ Dalam penelitian yang dilakukan di kelas IV tersebut dapat dilihat adanya bimbingan langsung dari guru kelas, sehingga siswa dapat mengembangkan aspek psikomotorik pada setiap tahapan psikomotorik yang dilaluinya.

\section{METODE PENELITIAN}

Metode penelitian ini adalah deskriptif kualitatif, data dikumpulkan dalam kondisi asli (natural setting) kemudian ditulis menjadi laporan berupa kata-kata. Peneliti mengumpukan dan mencatat data secara rinci berkaitan dengan masalah yang diteliti. Sampel diambil sedikit, dipilih menurut tujuan penelitian, dan subjek yang diteliti berkedudukan sama dengan peneliti. Teknik pengumpulan data yaitu instrumen berupa pengamatan dan wawancara terstruktur (mengarah pada susunan pertanyaan yang sudah direncanakan). Data yang diperoleh dianalisa, dilanjut mencari data lagi dan dianalisis, sampai dianggap mencapai hasil yang memadai. Data yang diperoleh peneliti di lapangan dapat dirumuskan menjadi kesimpulan atau teori. ${ }^{6}$ Subyek penelitian ini adalah siswa SDN Jambean 02 Pati yang berjumlah 5 siswa, terdiri dari 2 siswa laki-laki kelas III, 1 siswa laki-laki kelas IV, dan 2 siswa laki-laki kelas $\mathrm{V}$.

Teknis analisis data yang digunakan dalam penelitian ini adalah analisis interaktif, terdiri dari reduksi data, sajian data (display), dan penarikan kesimpulan (verifikasi). Reduksi data adalah cara yang dilakukan untuk mempertegas, memperpendek, membuat fokus, membuang hal-hal yang tidak penting, dan

5 Ramdhan Witarsa dkk, Meningkatkan Kemampuan Aspek Psikomotorik Siswa Sekolah Dasar Melalui Hands On Activity di Kota Cimahi, E-journal Basicedu Volume 1 Nomor 1 Tahun 2017, hal. 62,

6 Pupu Saeful Rahmat, Penelitian Kualitatif, Equilibrium, Vol.5, No. 9, Januari-Juni 2009, hal. 4 
mengatur data sedemikian rupa sehingga dapat menarik kesimpulan (memperoleh pokok temuan). Display data adalah penyajian data dengan baik dan jelas agar dapat dimengerti dan difahami. Sedangkan penarikan kesimpulan (verifikasi) sudah dimulai dari proses awal diperolehnya data. ${ }^{7}$ Data penelitian berupa hasil observasi dan wawancara dianalisis menjadi data yang jelas, mudah difahami, dan dapat disimpulkan.

\section{HASIL DAN PEMBAHASAN}

Berdasarkan data hasil penelitian mulai tanggal 27 April 2020 sampai dengan tanggal 15 Mei 2020 terhadap siswa SDN Jambean 02 Pati yang berjumlah 5 siswa, yaitu 2 siswa laki-laki kelas III, 1 siswa laki-laki kelas IV, dan 2 siswa lakilaki kelas V. Adapun temuan-temuan penelitian ini sebagai berikut:

\section{Pembelajaran Melalui Program TVRI}

Mendikbud meluncurkan pembelajaran melalui program TVRI di rumah untuk siswa dan guru selama pandemi covid-19. Program pembelajaran melalui TVRI sebagai alternatif media belajar bagi siswa jenjang PAUD sampai SMA yang wilayahnya memiliki hambatan dalam mengakses internet. Program pembelajaran melalui TVRI dilaksanakan karena adanya persoalan yang dihadapi selama pandemi covid-19, diantaranya belajar di rumah dengan memanfaatkan akses internet akan menemui hambatan bagi guru dan siswa yang berada di daerah tertinggal, faktor ekonomi menjadi salah satu faktor di mana siswa dan guru sulit untuk mengakses internet. Mendikbud berupaya agar siswa dan guru bisa mendapatkan sarana pembelajaran di tengah pandemi covid-19 dan akan mengevaluasi program tersebut bersama dengan lembaga non pemerintah yang independen. Evaluasi akan dilaksanakan untuk mengkaji kualitas program pembelajaran yang ditayangkan oleh TVRI. ${ }^{8}$

Berdasarkan penelitian yang peneliti lakukan terhadap siswa kelas III, IV, dan V SDN Jambean 02 Pati, mereka mengikuti program belajar dari pemerintah selama pandemi covid-19 dengan cara menyimak program TVRI sampai selesai. Untuk siswa kelas III, mereka menyimak bersama dengan teman dekat rumahnya, dengan tujuan jika ada soal yang sulit mereka bisa berdiskusi. Sedangkan siswa kelas IV ketika menyimak pembelajaran ditemani ibunya di rumah, ibunya yang memotivasi supaya ia semangat belajar, diakhir tayangan jika ada soal yang dianggap sulit ia meminta bantuan tantenya (rumahnya berdekatan). Untuk siswa kelas V ketika menyimak program TVRI ditemani kakaknya, biasanya jika ada kesulitan ia meminta bantuan kakaknya. Jawaban dari tugasnya dikumpulkan ke guru kelas masing-masing.

7 Subandi, Deskripsi Kualitatif Sebagai Satu Metode dalam Penelitian Pertunjukan, E-journal Harmonia, Volume 11 No.2 Desember 2011, hal. 178

8 Chandra Iswinarno dan Ria Rizki Nirmala Sari, Kemendikbud Luncurkan Program Belajar dari Rumah yang Akan Disisarkan TVRI, Kamis 09 April 2020 


\section{Aspek Psikomotorik Siswa}

Aspek Psikomotorik merupakan ranah yang berkaitan dengan keterampilan yang melibatkan fungsi sistem syaraf dan otot yang berfungsi psikis. Aspek psikomotorik terdiri dari tahap kesiapan (set), tahap pembimbingan (peniruan), dan tahap terampil dasar (membiasakan). ${ }^{9}$ Ketika siswa telah memahami apa yang telah dipelajarinya, pada tahap selanjutnya adalah bagaimana siswa mampu menerapkan pemahamannya dalam kehidupan sehari-hari melalui perbuatan.

\section{Tahap Kesiapan (set)}

Tahap kesiapan (set) adalah tahapan yang menunjukkan kesiapan siswa untuk bertindak baik mental maupun fisik. ${ }^{10}$ Berdasarkan hasil penelitian terhadap siswa SDN Jambean 02 yaitu siswa kelas III, IV, dan V. Ketika pembelajaran lewat TVRI dimulai, siswa menyimak dan memahami materi yang diberikan sampai materi selesai disampaikan. Dalam menyimak materi kadang siswa menyimak bersama ibunya, kakaknya, ataupun teman dekat rumahnya. Diakhir penyampaian materi, biasanaya siswa dikasih pertanyaan, siswa mengerjakan pertanyaan tersebut sesuai apa yang ia fahami, apabila ada pertanyaan yang dianggap sulit siswa tanya kepada orang tua atau kakaknya, atau mencari reverensi dari internet.

Hal ini menunjukkan bahwa pada tahap kesiapan siswa sudah melakukan tindakan untuk mengikuti program belajar dari rumah lewat TVRI meliputi menyimak, memahami materi, dan mengetahui cara atau langkah untuk menjawab pertanyaan setelah materi selesai disampaikan.

\section{Tahap pembimbingan (guided response)}

Aspek psikomotorik merupakan proses pengetahuan yang banyak didasarkan dari pengembangan proses mental melalui aspek-aspek otot dan membentuk keterampilan. Penelitian yang dilakukan oleh Fachruddin Azmi pada tahun 2017, pembimbingan belajar aspek psikomotorik siswa di MIS Amal Shaleh Medan disesuaikan dengan materi pelajaran, misalnya pada mata pelajaran akidah akhlak materi tentang asmaul husna, maka pembimbingan psikomotorik yang dilakukan dengan menyuruh siswa menghapal asmaul busna dengan nada nyanyian, ada juga dengan menulis asmaul busna dengan bentuk kaligrafi kemudian karya siswa ditempelkan di dinding kelas masing-masing. ${ }^{11}$

9Lorenzo M. Kasenda, dkk, Sistem Monitoring Kognitif, Afektif, dan Psikomotorik Siswa Berbasis Android, E-journal Teknik Informatika, Volume 9, No 1 Tahun 2016, hal. 2,

10 Hasyim Zaini, Desain Pembelajaran perguruan Tinggi, Yogyakarta, CTDS Sunan Kalijaga, 2002, hal. 62

11 Fachruddin Azmi, dkk, Pelaksanaan Pembimbingan Belajar Aspek kognitif, Afektif, dan Psikomotorik siswa di Madrasah Ibtidaiyah Swasta Amal Sholeh Medan, E-journal At-Tazakki Volume 1 No.1 Juli-Desember 2017, hal. 23-24 
Penelitian yang peneliti lakukan mengenai program belajar dari rumah melalui TVRI, untuk aspek psikomotorik tingkat pembimbingan dapat dilihat, misalnya pada hari rabu, 13 Mei 2020 materi untuk kelas I-III, cara menjaga amanah. Orang tua dapat memandu siswa memahami indtruksi lisan dari tayangan, dan untuk tugas tertulis, orang tua dapat membantu anak menuliskan baris demi baris tugasnya.

Untuk kelas tingkat tinggi (kelas 4-6), terkadang siswa diberikan tugas untuk membaca puisi di depan keluarganya pada selasa, 28 April 2020 pada materi Demam Puisi dengan tema keluarga, yang puisinya bisa dicari di internet. Ketika siswa membaca puisi didepan keluarganya, kemudian divideo dan hasilnya dikirim ke guru kelasnya.

Meskipun awalnya mereka dibimbing orang tua atau kakaknya tetapi pada saat divideo, siswa bisa membaca puisi dengan baik sesuai teknik membaca puisi. Pada tahap pembimbingan siswa meniru dan mencoba teknik membaca puisi sesuai bimbingan dari orang tua ataupun sesuai materi dari TVRI yang sudah disimak, meskipun pada awalnya terkadang siswa gagal, tapi mereka bisa membaca puisi sesuai teknik membaca puisi dengan baik.

\section{Terampil dasar (mechanism)}

Ketika siswa sudah memahami dan menginternalisasikan nilai-nilai mata pelajaran dalam dirinya, maka tahap selanjutnya adalah bagaimana siswa mampu mengaplikasikan pemahamannya melalui perbuatan atau tindakan, sejalan dengan teori belajar konstruktivisme bahwa pengetahuan siswa dibentuk karena mereka belajar aktif dari pada mereka hanya pasif (uninteresting). ${ }^{12}$

Berdasarkan data penelitian yang saya peroleh, pada hari rabu, 13 Mei 2020 materi untuk kelas I-III, yaitu cara menjaga amanah. Setelah siswa mengerjakan soal dengan bimbingan orang tua, diharapkan siswa mampu melaksanakannya dalam kehidupan nyata, yang dimulai dari kejujuran, tanggung jawab, dan disiplin.

Tahap terampil dasar merupakan kelanjutan dari tahap sebelumnya yaitu pembimbingan, ketika siswa mengikuti pembelajaran dari rumah melalui program TVRI dengan didampingi oleh orang tuanya atau kakaknya, maka siswa akan lebih mudah menerapkan materi yang dipelajari dalam tindakan dikehidupan nyata. Pada hari kamis, 7 Mei 2020 (bertepatan dengan hari libur), maka program pembelajaran untuk kelas IV-VI diganti membuat origami, diharapkan agar siswa dapat berlatih membuat origami, baik untuk mengisi waktu luang di rumah, maupun untuk melatih keterampilan siswa. Diakhir

12 Woro Kristiningtyas, Peningkatan Hasil Belajar Siswa Aspek Kognitif dan Psikomotorik dalam Membuat Sketsa dan Peta Wilayah yang Menggambarkan objek. Geografi melalui Metode Survei Lapangan, E-journal Refleksi Edukatika Volume 8 No. 1 Tahun 2017, hal. 33 
program pembelajaran mengenai pembuatan origami tidak ada penugasan bagi siswa untuk membuat kerajinan origami, karena pada saat penyampaian materi kerajinan origami bertepatan dengan hari libur.

Berdasarkan penelitian yang saya lakukan untuk siswa kelas IV, V, dan VI, siswa tersebut tidak berlatih membuat origami, dikarenakan tidak ada kewajiban untuk mengumpulkan tugas origami. Nah disinilah adanya ketidak aktifan siswa, karena ia hanya menyimak materi saja tanpa mengikutinya dengan tindakan, sehingga siswa tidak bisa mengembangkan keterampilan yang dimiliki dalam kehidupan nyata.

\section{Pembelajaran di Tengah Pandemi Covid-19}

Kebijakan pemerintah Indonesia untuk melaksanakan pembelajaran dengan cara daring (dalam jaringan) menyebabkan kebingungan dari berbagai pihak. Perubahan cara belajar yang awalnya tatap muka di kelas menjadi virtual menyebabkan digitalisasi pendidikan, tanpa ada pembatas dan ruang kelas ketika belajar, semuanya beralih menggunakan teknologi tanpa harus bertemu. Dalam pelaksanaanya, proses pembelajaran secara daring masih mengalami hambatan. Perubahan cara belajar secara konvensional yang digantikan dengan digitalisasi mengharuskan semua pihak untuk beradaptasi.. ${ }^{13}$

Mendikbud Nadiem Makarim mengatakan adanya pandemi covid-19 memberikan pelajaran kepada seluruh elemen pendidikan, mulai guru, siswa, hingga orang tua. Bagi guru dan siswa, harus beradaptasi dengan menggunakan metode pembelajaran dalam jaringan (daring), dan menyadari bahwa proses pembelajaran bisa dilakukan di manapun (tidak harus di sekolah). Orang tua siswa menyadari betapa sulitnya tugas guru untuk mengajar dan mendidik siswa di sekolah, dan diharapkan memiliki empati kepada guru terkait dengan tugas-tugas siswa untuk belajar dari rumah. ${ }^{14}$ Dengan adanya kesadaran orang tua terhadap tugas belajar siswa yang dilaksanakan dari rumah, maka diharapkan orang tua siswa dapat memberikan perhatian dan bimbingan ketika siswa belajar dengan tujuan supaya siswa dapat mengembangkan aspek psikomotorik sesuai tahapan yang dilaluinya.

Berdasarkan hasil penelitian, peneliti menemukan adanya kesadaran dari orang tua atau keluarga ketika siswa mengikuti pembelajaran dari rumah, mereka memberikan perhatian dan bimbingan, dengan tujuan supaya siswa mampu mengembangkan aspek psikomotorik sesuai tahapan yang dilaluinya. Oleh sebab

13 Isnan Nursalim, Digitalisasi Pendidikan di Tengah Pandemi Corona, 27 April 2020

14 Rahmad Fauzan, Pesan Nadiem Tentang Pendidikan di Tengab Pandemi Corona, Sabtu 2 Mei 2020 
itu, peran orang tua sangat penting dalam proses belajar siswa selama sistem daring dalam pembelajaran di rumah ${ }^{15}$.

\section{KESIMPULAN}

Hasil penelitian yang peneliti lakukan terhadap siswa SDN Jambean 02 Pati yang melaksanakan pembelajaran dari rumah melalui program belajar TVRI selama penyebaran pandemi covid-19, menunjukkkan adanya pengaruh terhadap aspek psikomotorik siswa, meliputi 3 tahap yaitu kesiapan, pembimbingan, dan terampil dasar. Pada tahap kesiapan siswa sudah melakukan tindakan menyimak, memahami materi, dan mengetahui cara (langkah) untuk menjawab pertanyaan. Pada tahap pembimbingan, siswa dibimbing orang tua atau orang yang lebih dewasa untuk menyelesaikan tugasnya. Pada tahap terampil dasar, siswa dilatih untuk menerapkan materi yang dipelajari dalam kehidupan nyata, tetapi belum berhasil.

Pembelajaran dari rumah lewat program belajar TVRI dengan bimbingan orang tua atau orang dewasa berpengaruh terhadap aspek psikomotorik siswa pada tahap kesiapan dan pembimbingan, namun pada tahap terampil dasar belum berhasil. Hal ini menunjukkan peran guru di sekolah tidak bisa digantikan oleh teknonogi, meskipun ketika siswa belajar di rumah didampingi oleh orang tua. Dengan adanya pembelajaran dari rumah melalui program TVRI, diharapkan orang tua dapat membimbing siswa ketika belajar dengan tujuan supaya aspek psikomotorik siswa dapat berkembang dengan baik sesuai tahap perkembangannya.

\section{DAFTAR PUSTAKA}

Ahsani, E. L. F. Strategi Orang Tua dalam Mengajar dan Mendidik Anak dalam Pembelajaran At The Home Masa Pandemi Covid-19. Al Athfal: Jurnal Kajian Perkembangan Anak dan Manajemen Pendidikan Usia Dini. 2020. 3(1).

Azmi, Fachruddin, dkk. Pelaksanaan Pembimbingan Belajar Aspek kognitif, Afektif, dan Psikomotorik siswa di Madrasah Ibtidaiyah Swasta Amal Sholeh Medan. E-journal At-Tazakki Volume 1 No.1 Juli-Desember 2017.

Fauzan, Rahmad. Pesan Nadiem Tentang Pendidikan di Tengah Pandemi Corona. Sabtu 2 Mei 2020.

Harususilo, Yohanes Enggar. Belajar dari Rumah Lewat TVRI, Berikut Tayangan yang Akan Diberikan. Jum'at 10 April 2020.

15 Eva Luthfi Fakhru Ahsani, Strategi Orang Tua dalam Mengajar dan Mendidik Anak dalam Pembelajaran At The Home Masa Pandemi Covid-19. Al Athfal: Jurnal Kajian Perkembangan Anak dan Manajemen Pendidikan Usia Dini, 3(1), 37-46. 
Iswinarno, Chandra dan Ria Rizki Nirmala Sari. Kemendikbud Luncurkan Program Belajar dari Rumah yang Akan Disisarkan TVRI. Kamis 09 April 2020.

Jamaluddin, Didi Nur. 2018. Pengembangan Evaluasi Pembelajaran. Kudus: IAIN Kudus.

Kasenda, Lorenzo M., dkk. Sistem Monitoring Kognitif, Afektif, dan Psikomotorik Siswa Berbasis Android. E-journal Teknik Informatika, Volume 9, No 1 Tahun 2016.

Kristiningtyas, Woro. Peningkatan Hasil Belajar Siswa Aspek Kognitif dan Psikomotorik dalam Membuat Sketsa dan Peta Wilayah yang Menggambarkan objek Geografi melalui Metode Survei Lapangan. E-journal Refleksi Edukatika Volume 8 No. 1 Tahun 2017.

Nursalim, Isnan. Digitalisasi Pendidikan di Tengah Pandemi Corona. 27 April 2020.

Rahmat, Pupu Saeful. Penelitian Kualitatif. Equilibrium, Vol.5, No. 9, Januari-Juni 2009.

Rezkisari, Indira. Belajar Lewat TVRI tak Bisa Gantikan Program Buatan Sekolah. Selasa 14 April 2020.

Subandi. Deskripsi Kualitatif Sebagai Satu Metode dalam Penelitian Pertunjukan. Ejournal Harmonia, Volume 11 No. 2 Desember 2011.

Sukardi. 2009. Evaluasi Pendidikan: Prinsip dan Operasionalnya. Jakarta: Bumi Aksara.

Witarsa, Ramdhan, dkk. Meningkatkan Kemampuan Aspek Psikomotorik Siswa Sekolah Dasar Melalui Hands On Activity di Kota Cimahi. E-journal Basicedu Volume 1 Nomor 1 Tahun 2017.

Zaini, Hasyim. 2002. Desain Pembelajaran perguruan Tinggi. Yogyakarta: CTDS Sunan Kalijaga. 